\title{
A Policy Change Effected through a Change in the Meaning of Target Populations: A Case Study of South Korea's Limited Internet User Self-Identification Policy*
}

\author{
Sungeun Cho** and Sang-hoon Ahn***
}

\begin{abstract}
This study examines the process of policy change, drawing on the theory of the social construction of target populations to explore South Korea's limited Internet user self-identification policy. In the early 2000s, the government directly imposed on netizens and service providers by establishing regulations that resulted in netizens being categorized as deviants. Then, as personal data spillage became a problem and the market environment changed, netizens and Internet service providers were transformed into the advantaged group needing protection. Consequently, the government relaxed its regulations and allowed Internet users to self-regulate instead. This study verifies that the process of change in the way target populations are viewed is caused by an interaction between a structure and its actors. Furthermore, positive political and economic events and social movements can rapidly transform actors, Internet users and service providers in this case, into an advantaged group.
\end{abstract}

Keywords: policy change, target population, social construction, Internet regulation policy

\section{INTRODUCTION}

As Lasswell (1951) suggested, achieving a policy science of democracy, the ultimate goal of policy sciences, requires that close attention be paid to the policy process to

\footnotetext{
* An earlier version of this article was presented at 25th Annual Meeting of the Public Administration Theory Network in Texas, U.S.A on 18 May, 2012. And the authors wish to thank three anonymous reviewers for their valuable comments.

** Sungeun Cho is a senior researcher at the Institute of Governmental Studies in Korea University. E-mail: cseongeun@gmail.com.

*** Sang-hoon Ahn is a PhD candidate at Korea University. E-mail: fireashedsoul@ gmail.com.

Manuscript received October 2, 2015; out for review October 20, 2015; review completed November 16, 2015; accepted December 12, 2015.
}

The Korean Journal of Policy Studies, Vol. 30, No. 3 (2015), pp. 63-89.

(C) 2015 by the GSPA, Seoul National University 
ensure that appropriate policies are being planned and carried out for target populations. Schneider and Ingram (1993) pointed out that the meanings of target populations are not fixed but are rather liable to change with time. Thus, it is appropriate for policy sciences to continuously track perceptions of target populations, as this helps them fulfill their goal of promoting more appropriate policy. Accordingly, this study examines the effect of a limited Internet user self-identification policy to demonstrate how the process of policy change is related to the changing meaning of target populations.

Today, about 20 years after commercialization of Internet, there are still serious debates over Internet regulation. While some people argue that self-regulation is appropriate considering the characteristics of the Internet, others suggest that government regulation is necessary to minimize undesirable side effects of Internet usage given that the Internet is no longer merely a virtual world but has effectively joined the real one (Christou \& Simpson, 2006; Ang, 2009).

In South Korea, controversies over Internet regulation are represented in microcosm by attempts to change Internet regulation policy. Discussions about the necessity of Internet regulation arose in 2001 and after that, successive regulations in 2004, 2007, and 2009 were strictly enforced in connection with online discussion boards, blogs, emails, and the uploading of video clips to websites. Then, in 2012, after a decision by Korea's constitutional court, the ban on posting content in support of or opposition to a candidate for political office was lifted.

Although Internet regulations in South Korea have consistently targeted Internet service providers and netizens, the meaning of these populations has changed over time, which has turn led to changes in policy. This study examines the time-variant significance of Internet service providers and netizens in order to understand the dynamic nature of a limited user self-confirmation policy through simultaneously occurring path-dependent preservation, reinforcement, and final abandonment of this policy.

This study draws on social constructivism to analyze Korea's limited user selfidentification policy. Social constructivism is useful because it pays attention to the process of policy construction through interaction of structure and actors. A dynamic Internet regulation process in which diverse changes including path-dependence and policy abandonment manifest themselves can therefore be effectively comprehended by drawing on this theory. Social constructivism is also a good tool for analyzing Internet regulation considering its focus on policy target populations whose meanings change over time.

Our analysis covers the period from 2001, when discussions about the necessity of regulation arose, to August 2012, when the limited user self-identification policy was finally abolished and self-regulation by Internet service providers began. We looked at 
sources such as official documents and minutes of the government and National Assembly of South Korea, related research, and press data.

\section{THEORETICAL BACKGROUND}

\section{Social Constructivism and Policy Change Problems Related to Practical Values}

In the 1970s, the policy sciences expanded rapidly as behaviorist theories waned in popularity. The emphasis on scientific methodology was criticized, however, on the grounds that it could lead to the avoidance of value judgment and the neglect of practical value. In spite of such criticism, research in political sciences that applied scientific methodology, mainly in the fields of policy analysis and evaluation, such as policy efficiency and effectiveness, became mainstream. Such research has contributed to solving certain policy problems, but some aspects of policy cannot be analyzed through objective indicators or technical and economical reasoning alone. Social constructivism can help uncover the hidden reasons why a certain policy is decided on or changed in a particular way, and what it reveals not only complements the rational approach but also contributes to a more fundamental understanding of the policy (Kim, 2005, p. 32).

Social constructivism starts from the hypothesis of antiessentialism, the theory that reality is a social construction (Berger \& Luckmann, 1966; Burr, 2003). This view refutes the hypothesis that objects have essences. The world is only socially constructed. Policy, according to social constructivism, is a process underwritten by the values of a given society rather than by abstract reason. In addition, because values can change according to sociocultural context, policy is not fixed and objective, but neither is it unstable.

Social constructivism challenges conventional positivism and experimentalism, and since target populations in social constructivism are subjectively constructed, it emphasizes the interpretation and understanding of wide-ranging target characteristics (Burr, 2003, pp. 2-5). Thus, if we apply this idea to policy, the source of policy decisions or changes can be studied through the meaning that diverse participants bring to the policy-making process and the notes the participants strike to justify the policy (Kim \& Ahn, 2006). ${ }^{1}$ Thus, policy is ultimately the process of managing contradictions and

1. Many other frameworks for understanding policy change have been proposed. In their research, Hogwood and Peters (1983) make the distinction between policy maintenance, succession, termination, and innovation. Policy maintenance is the process of making adaptive changes to existing policies with no fundamental revisions to regulations or basic 
legitimately satisfying various aspects, particularly ethical, political and religious ones (Majone, 1989).

\section{SOCIAL CONSTRUCTION AND SOCIAL FORMATION MODEL OF TARGET POPULATIONS}

\section{The Social Construction of Target Populations}

Social constructivism focuses on the influence on actors of structural variables such as historical and cultural contexts and the system. Although social reality and policy changes are made though interactions between the actors, these interactions occur in a certain context, situation, and social regulatory climate. Furthermore, because each actor experiences these situations differently, our understanding of social context should be informed by this fact (Cronley, 2010, pp. 320-321). It is not only the interactions between actors that occur in a specific context but also social and political problems, so consideration of the structure and context is necessary to understand a phenomenon (Conrad \& Barker, 2012).

Social constructions are a result of interactions between actors using language (Gergen, 2009). Actors are individuals who see the world differently and bring their unique understanding to bear in their interactions with others. Actions do not exist in isolation from each other but become a cause of further action by other actors. Actors'

policies. Policy succession entails a discontinuing or an adding of an important piece to a policy, indicating there has been a change in the basics constituting the existing policy. Policy termination occurs when an existing policy is terminated, such as when projects implementing the policy are abandoned without any definitive alternatives to the terminated policy being supplied. Governments may establish new policies by entering into new areas in which they previously did not engage; this constitutes policy innovation. Another framework, proposed by Hall (1993), divides policy change into first-, second-, and third-order changes. A first-order change in a policy does not fundamentally change the policy goal or instrument. A second-order change results in a shift in the policy instrument, but the goal remains largely the same. A third-order change is a radical change that alters both policy goal and instrument. Mucciaroni (1995) views policy change as a dramatic change in policy before its implementation, whereas Lowry (2006) adds duration as a factor, breaking policy change down into four categories: major change, episodic change, gradual change, and isolated change. Despite the diversity of research dedicated to policy change, all views agree that policy changes as contents change. In the case of South Korea's limited user self-identification policy, the instruments and contents of the regulation have changed continuously, placing it in the category of second order-change or policy succession. 
interactions create the social structure and situation and reproduce them (Edvardsson, Tronvoll, \& Gruber, 2011). Social constructivism examines how the interactions among actors contribute to the construction of social phenomena (Conrad \& Barker, 2012, p. S67).

Similar accounts of the construction of social reality can be found in morphogenetic social theory and actor-centered institutionalism. Drawing on morphogenetic social theory, Archer (1995) and Kim (2009a) have suggested that under the emergent attribute of structure or casual power, respectively, the interactions between principal actors are linked to the reproduction and transformation of systems. In addition, Scharpf (1997; 2000), Kim (2009b), and Ha (2009) have recognized the influence of actors on institutions, using the theory of actor-centered institutionalism to explain how policies are maintained and changed. ${ }^{2}$

Actors' interactions occur within the social structure, but at the same time actors reproduce the social structure through that interaction (Powell \& Hendricks, 2009, p. 86), and so the way target populations are perceived is also the product of the interactions between structure and actors.

Existing research on the social construction of target populations focuses on structural variables more than actors' interactions. Schneider and Ingram (1993, p. 355) explain that the politics, culture, socialization, history, media, literature, and religion of a given area render this or that group the archetype of it. Donovan (1993) pays attention to the effect of environmental variables such as historical categories that are related to problems of policy and public events. In addition, Schneider and Ingram (2005) put various aspects together and then subdivide the causes of change in the meaning of target populations into external events, social events, social movements, entrepreneurial spirit, policy design, development of science technology, development of social science, and demographic changes, but their theory is also inclined to a structural point of view. Since actors are the ones who directly form social meaning, however, actors' interactions are necessarily analyzed with the variables.

In addition, there has been limited research into the reasons why target populations are perceived the way they are and about the process of change in those perceptions that might reveal under what conditions they remain constant and under what conditions they change rapidly (Donovan, 1993; deLeon, 2005).

2. According to the theory of actor-centered institutionalism, policies are influenced by institutional setting, the ability and orientation of the actors, constellations consisting of strategy combinations and payoffs, and modes of interaction (Scharpf, 1997, p. 44). 


\section{The Social Construction Model of Target Populations}

The social construction model of target populations, as explained by Schneider and Ingram (1993), makes a connection between social constructivism and policy and develops a theoretical framework to account for that connection (Schneider \& Sidney, 2009). The social construction of target populations is the characterization of target populations in certain forms. This construction indicates the recognition of shared characteristics that distinguish a large population as socially meaningful and the attribution of specific, valence-oriented values, symbols, and images to these characteristics (Schneider \& Ingram 1993, p. 335). Policy targets can be divided into four categories according to how they are socially constructed and their degree of power: the advantaged, contenders, dependents, and deviants. The various groups that make up these categories can overlap. Figure 1 shows how various target populations are viewed on a spectrum from positive to negative and their relative degree of political power.

Target populations for our purposes are groups of individuals who receive benefits or are subjected to the sanction of policies, and they are different from interest groups. Social constructions can be used as indicator of whether others might approve or disapprove the policy directed toward a particular target, and the degree of power can be used to predict voting patterns, gauge wealth, and ascertain the propensity of the group to mobilize for action. The content of a given policy will vary according to population that the policy is targeting. Elections in democratic countries provide motivate politicians to appeal to voters, and so policy makers tend to sensitively respond to citizens' demands. However, within this system, when people without power are recognized positively or people with power are recognized negatively, it is not easy to tailor policy for them (Donovan, 1993, p. 7).

The advantaged are both politically powerful and viewed in a positive way. The general public has a positive attitude about the advantaged population. Such a positive attitude engenders a minimal amount of resistance on the part of the public to policies that are designed support the interests of the advantaged, which are represented as being for the public good.

Contenders are a politically powerful but negatively perceived group. Members of this category include conglomerates such as insurance companies and labor unions. Despite their power, their image is negative, and therefore, policies benefiting this group are often pursued secretly. During elections, candidates design policies to pressure this group in order to win voters; nonetheless, due to the group's strong political resources, such policies may merely be symbolic gestures.

Dependents belong to a group that is constructed positively but whose political power is weak. Children as well as the poor are included in this category. While they 
Figure 1. Social Construction of Target Populations

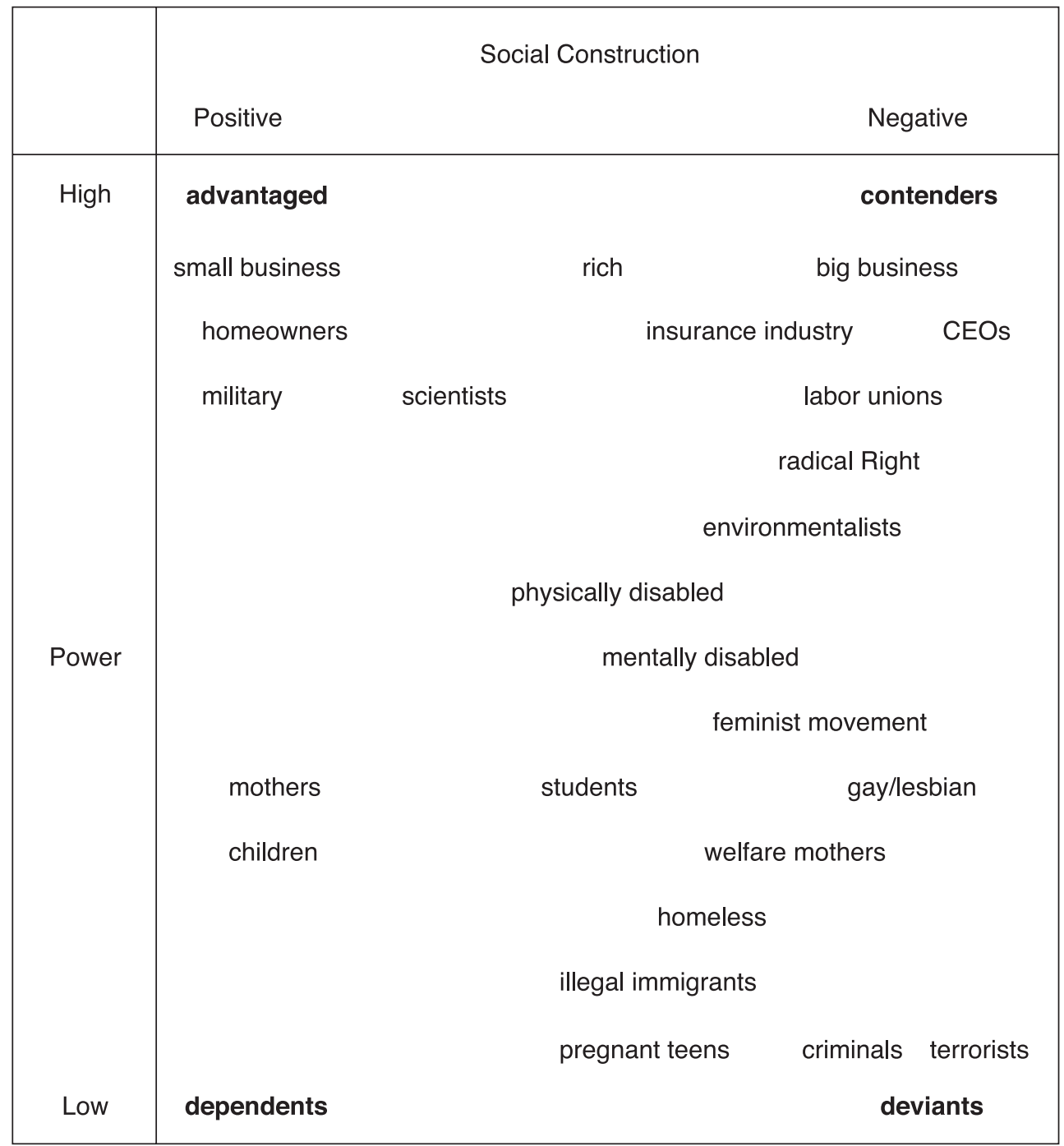

Source: adapted from Ingram, Schneider, \& deLeon 2007, p. 102; Schneider \& Sidney 2009, p. 107.

are viewed positively, dependents are seen as people in need of help. However, due to this group's lack of political power, policies beneficial to them may not be forthcoming. Vote-seeking politicians tend to pledge empty policies that do not much help this group.

Deviants, such as criminals or illegal immigrants, struggle with a negative social perception and weak political resources. They are the objects of derision and hatred 
and are segregated from society. Since they lack political resources and are perceived negatively, policies that are punitive and that have limited benefits are applied to them.

The social construction of target populations is useful in seeing how the same target population may be characterized differently in different places and how consequently policies designed for that population might differ depending on location. Carney (2010) explains, for example, that the meaning of senior citizens in the U.K. is different from the United States. While senior citizens in the United States are part of the advantaged group, they are categorized as dependents in the UK. In consequence, Carney explains that policy for senior citizens in the UK is designed unreasonably and extemporaneously.

In addition, the social construction of target populations helps us understand the dynamics of policy change (Schneider \& Ingram, 1993, p. 346). Ingram and Schneider (1995) present three ways target populations can affect policy change. First, the meaning of the target populations can change after operant learning. If the advantaged group becomes greedy and selfish, they may end being categorized as contenders. Or deviants may become contenders by developing their own political power, and therefore a policy that burdens such groups may be weakened or diminished. Second, policy can be changed by external factors, such as an entrepreneur or external events. Lastly, without operant learning or external influence, the existing meaning of a target population may simply be retained. In other words, as social construction and policy form a bond through reciprocal reinforcement, an advantaged group continuously secures advantages and a deviant one is punished.

Among the aforementioned three routes, operant learning best explains the gradual change in the image of target populations over a relatively long time period, given that learning itself is a gradual process. The third route accounts for the consolidation of stereotypes rather than for changes in them, and the real possibility of making circular errors when analyzing interactions between these target populations and policy should be considered. On the other hand, external influences can effect both radical and gradual policy changes. When external influences render the meaning of a target population constant, policy changes only gradually. However, when an external event effects a big change in the way a target population perceived, radical changes in policy can follow.

There are caveats to using the social construction of target populations to understand policy changes. One is that, as Ingram and Schneider (1995) point out, it is the citizen's perceptions and beliefs about government and politics that matter most. However, research tends to pay more attention to the perceptions of legislators. For example, Schroedel and Jordan (1998) analyze influential U.S. senators' perceptions of target populations and the role those perceptions play in the drafting of policy. Policy makers, especially politicians, may respond to citizen's beliefs sensitively because they are seeking votes. However, this does not mean that they consider citizens' perceptions of 
themselves and others. Therefore, a distinction between the way politicians and citizens view target populations should be made, so that their distinct influences can be analyzed separately and also so that the interactions between them considered.

\section{EXISTING STUDIES AND LIMITATIONS}

The exploration of how the social construction of target populations can account for policy changes has been most pronounced in connection with immigration and welfare services (Jensen, 2005; Newton, 2005; Bensonsmith 2005; Schram, 2005). For example, a study conducted by DiAlto (2005) analyzes the transformation of immigration policy with respect to Japanese Americans. After World War II, Japanese Americans were portrayed negatively and faced discriminatory policies. Nevertheless, through organized efforts, Japanese Americans reinvented their image as model immigrants and were eventually granted citizenship under the Immigration Act of 1952. In their analysis of welfare policies, Jurik and Cowgill (2005) illustrate how different policy targets can influence the outcome of a policy. The microenterprise development program was introduced in the United States to support low-income workers who could not afford independent living. However, as the policy target shifted to the middle class, the policy lost momentum and could not achieve what had been hoped for it. Although the social constructivist approach to target populations has been most widely used in examining policies aimed at neglected classes (owing to Schneider and Ingram's [1993] focus on social prejudice and the pursuit of a democratic policy science), recent studies have demonstrated that the model's theoretical explanation is more widely applicable.

The social constructivist approach to target populations has not yet been applied to Internet regulation, however. It is a useful way to examine the limited Internet user self-identification policy, though, because it has changed along with the policy target population, which consists of Internet service providers and netizens. The changing meaning of those who were regulated or protected because of the policy is likely an important factor that led to changes in it over the course of the first decade of the twenty-first century. Korea's limited Internet user self-identification policy has been studied from other perspectives. One group of studies explores the logic of the support for and against the policy, summarizes the debate over it, and provides a comparison of alternatives to it (Kang, 2003; Huh \& Baek, 2006; Hwang, 2007; Choung, 2009; Jang, 2011). Another group of studies presents results considers policy-making procedures and discourse formation in policy adoption and abandonment (Seo, 2008; Lee, 2008; Jho \& Kim, 2010; Sung, 2014). But our research is distinguished from these studies in 
that we treat the changing perception of the policy target population as a factor in inducing policy change.

\section{ANALYTIC FRAMES}

As already noted, while Schneider and Ingram (2005) demonstrate factors that influence the change in the meaning of target populations, they focus external variables, and they also pay less attention to interactions among the actors. In addition, they cannot provide an explanation of how changes in target populations come about and whether those changes are radical or gradual.

In our study, therefore, we classify the variables that induce changes in the way target populations are viewed based on their properties and examine how target populations change depending on these properties. If the variables exercise their influence restrictively, the change in the way target populations are viewed will be gradual. On the other hand, if the variables exercise their influence extensively, the influence is far-reaching and the change will be radical. Table 1 categorizes the various configurations that are possible depending on whether the effect of the variable is restrictive or far-reaching.

Policy targets are divided into populations that are regulated and populations that are protected, as the limited user self -identification policy is a type of regulatory policy. As regulatory targets, netizens (those who use the Internet or information and communication services furnished by service providers [Lee, Karen, \& Lee, 2005]) had to have their identity confirmed before they were allowed access to message boards. Those affected by South Korea's limited Internet user self-identification policy are netizens; however, the legislation's target is the information and communication services providers, that is, those who operate to earn profit through the use of the services they supply. Hence, providers have been analyzed in this study, and we also consider the

Table 1. The Process of Change in Target Populations according to the Degree of Influence

\begin{tabular}{l|l|l|l}
\hline \multicolumn{2}{|c|}{} & \multicolumn{1}{c}{ Restrictive Influence } & \multicolumn{1}{c}{ Extensive Influence } \\
\hline \multirow{4}{*}{ Positive } & Image & gradual change to dependent & radical change to dependent \\
\cline { 2 - 4 } & Power & gradual change to contender & radical change to contender \\
\cline { 2 - 5 } & image/power & gradual change to advantaged & radical change to advantaged \\
\hline \multirow{3}{*}{ Negative } & Image & gradual change to contender & radical change to contender \\
\cline { 2 - 5 } & Power & gradual change to dependent & radical change to dependent \\
\cline { 2 - 5 } & image/power & gradual change to deviant & radical change to deviant \\
\hline
\end{tabular}


question of why regulations were devised to center around them.

As the limited Internet user self-identification is a type of a regulatory policy, there are populations that benefit from it as well as populations burdened by it. We take a close look at those who have benefited from this policy in order to gain in-depth understanding of the drivers of policy change. The objective of the real-name policy was to protect netizens from cyberbullying, which is why we use the term "protected group" rather than "benefiting group." We divide these protected groups into the categories of nation, citizen, and business.

In addition, we analyze policy targets in terms of their social identity and political identity. Political identity is recognized by policy makers such as the government and politicians, and social identity is recognized by NGOs and public opinion. Existing studies examine the identity of target populations based on either their political or their social identities on the assumption that they are similar. However, we see these as two separate dimensions and accordingly treat them as such.

\section{CHANGE IN THE LIMITED INTERNET USER SELF-IDENTIFICATION POLICY}

\section{Implementation of a Temporary Preregulatory Provision}

The limited Internet user self-identification policy was formally introduced through a 2004 amendment to the Election of Public Officials and the Prevention of Election Malpractices Act. With this revision, real-name authentication became obligatory. Internet users now had to confirm their social security number and real name before posting information on Internet message boards relating to the candidates during election season. Additionally, Internet media had to install programs to allow for real-name authentication. Real-name authentication had the effect of official dividing the policy target populations into protected population and regulatory populations.

\section{Implementation of a Permanent Preregulatory Provision}

In 2007, Internet usage became subject to constant instead of just periodic regulation when an amendment to article 44 of the Act on Promotion of Information and Communication Network Utilization and Information Protection that allowed for a limited verification of identity was enacted.

With the introduction of a limited verification of identity, the population subject to regulation was expanded on the basis of the number of users rather than according to 
the content of the postings. The object of regulation of the amended act was all message boards that were served by portal sites, UCC board sites that consistently had over 300,000 daily visitors and boards provided by the Internet press that consistently had over 200,000 visitors a day. The amendment also had the effect of partially restricting netizens' anonymity when they posted to Internet message boards, and the freedom of Internet companies was compromised by their having to install programs that ensured limited verification of identity.

\section{Implementation of Permanent Pre- and Postregulatory Provisions}

The regulation of limited verification of identity expanded on a wide range. After a 2009 revision to the enforcement ordinance of the information and communication network utilization act, all message boards with over 100,000 daily visitors served by Internet service providers became subject to regulation. The types of services regulated by the act were also expanded and included services such as shopping and bidding, games and entertainment, leisure, finance, business, and education services (Korea Communications Commission, 2009; 2010, 2011a), and the number of Internet services subject to regulation was also greatly expanded. Restrictions were imposed on 138 sites in 2009, 156 sites in 2010, and 146 sites in 2011.

\section{Maintenance of Temporary Regulation and Abolition of Permanent Regulation}

Regulations regarding Internet usage changed when the limited verification of identity requirement was rescinded and real-name authentication was retained in 2012 (Korea Communications Commission, 2012). Policy change was centered on enforcing self-regulation by private Internet service providers and restricting government intervention. However, temporary regulations that had been included in the election act were maintained. According to the policy change, real-name authentication would be required only in election seasons.

\section{A SOCIAL CONSTRUCTIVIST APPROACH TO CHANGES IN THE LIMITED INTERNET USER SELF-IDENTIFICATION POLICY}

\section{Formation in the Meaning of the Policy Target Population}

By the early 2000s, Korea had high-speed Internet access, and the social leverage of the Internet had been gradually expanding in accordance with the growth in the 
number of Internet users (Korea Ministry of Information and Communication and Korea Network Information Center, 2004), which in turn had an effect on elections. Internet election campaigns had begun to make a mark owing to their low cost and strong effect in the 2000 National Assembly elections and the 2002 presidential election (Cho, 2009, pp. 228-246). However, the election act had not been revised during that time to allow it regulate new voter activities such as Nosamo (Internet supporters for Roh Moo-hyun, a presidential candidate) and Changsarang (Internet supporters for Lee Hoi-chang, another presidential candidate) or Internet-based election campaigns and reports by the Internet press (Park, 2010, p. 28; Kim, H. K, 2005, pp. 203-204; Cho, 2007, pp. 58-59). A consensus arose for the need for a policy that would maintain democratic order and protect politicians against defamation and groundless rumors (National Assembly, 2004a).

During the debate on the revised bill, Nationwide Political Reform Council advised the National Assembly to introduce the real-name system that Internet users to confirm their identity and that prohibited the use of nicknames on the message boards (Park, 2003). ${ }^{3}$ The recommendation of the council expressed awareness of a desire to protect the parties from negative political activities on the Internet. As Internet regulation for protection to maintain democratic order was socially agreed upon, it was possible to socially construct politicians as the advantaged group.

However, formation of the social construction of netizens and Internet press was more complicated because it had to serve the purpose of justifying their bearing the social burdens of regulation. Politicians argued that netizens should bear the social burden in order to protect democratic order, and so they represented netizens as the deviant group. In the proceedings of the special political reform committee of the National Assembly, politicians remarked on how netizens engaged in "linguistic violence" by insulting and defaming candidates on the Internet. And they insist that a full-scale real-name system with electronic certificate published by the government must be imposed that use for confirming user identity (National Assembly, 2004a, 2004b).

However, civil society strongly opposed politicians' representations of netizens. NGOs argued that the regulation requiring netizens to secure an electronic certificate that confirmed their identity in order for them to be able to post on boards during election season was too excessive. To NGOs, using Internet boards and replying to Internet press reports were part of a process of social communication and anonymous political participation. NGOs held a press conference in December 2003 and February 2004,

3. The Nationwide Political Reform Council was a temporary consulting organization for the chairman of the National Assembly, consisting of politicians, NGOs, and lawyers for the election act amendment. 
during which they argued that the legislation to introduce a full-scale real-name system should be withdrawn as it could violate freedom of expression and free communication on the Internet. ${ }^{4}$ NGOs thus sought to represent netizens as an advantaged group that had the potential to establish a new political culture.

Differences in the way politicians and social organizations viewed netizens contributed to the process of constructing their policy identity. The opposition parties (the Democratic Party and Our Open Party) offered an approach that could reconcile these different views. The committee member of the opposition parties offered alternatives that would minimize the burden place on netizens (National Assembly, 2004b). The result was that the netizen was constructed as a policy target population that should be regulated to a degree but that should not be subjected to a full-scale real-name system. Netizens were required to enter their real name and social security number before they would be allowed to use the message board, but they were not required to use their real name on the message board itself.

The way the political message boards themselves were socially constructed was also an important factor in determining how strong to make the regulation. The number and influence of Koran media websites had grown (Ohmynews and the Pressian, Korean Internet newspapers, were ranked 6th and 13th, respectively, in 2003 in an annual survey of Korean media in Sisa Journal, a Korean weekly magazine) ${ }^{5}$ and the depth, diversity, speed, and informative aspect of reporting on Internet media websites had earned these sites recognition as an alternative press. In addition, they were considered to be consumer-centered media that readers-Internet users-could access more easily and that afforded expression of more diverse opinions than traditional media (Korea Press Foundation, 2001, p. 16). But despite these accolades, the negative view proffered by the National Assembly of Internet boards and media as sites that upset the democratic order and that encouraged defamation and slandering under the cloak of anonymity prevailed, and Internet media as a policy target population came to be identified as contenders, with the result that both the media as news producers and the portal sites

4. See "Putting a gag on the Internet press with electronic signatures raises concerns of a replay of illegal election campaigns," Hankyoreh, December 25, 2003, http://legacy.www.hani. co.kr/section-001037000/2003/12/001037000200312251746025.html; "We are deceived by politicians again," Pressian, July 1, 2014, http://www.pressian.com/news/article.html? no $=8569$.

5. See "Who moves Korea? The press part / KBS at night, Chosun Ilbo in the daytime," Sisa Journal, October 21, 2003, https://www.sisapress.com:444/news/articleView.html?idxno= 122. See also "KBS is ranked1st and Chosun Ilbo is 2nd in the media source with influence," Mediatoday, October 20, 2003, http://www.mediatoday.co.kr/news/articleView.html?idxno= 23677. 
as news deliverers were forced to bear the burden of installing and operating real-name system programs (although in reality the burden was more or less symbolic because a large number of Internet media were already using membership method similar to realname systems at the time). Members of National Assembly also proposed a further revision to related act that would require Internet media to register with the government in order to acquire legal status.

\section{Disambiguation in the Meaning of the Policy Target Population}

The limited Internet user self-identification policy had expanded from temporary and narrow regulation to permanent and wide-ranging regulation of Internet message boards-especially for major portal sites. These policy changes were the result with social events related to Internet message boards were used and the changing social construction of the policy target population. The Korean government saw the realworld effects of Internet use as dangerous. It wasn't just politicians who suffered, but members of the general public, including teenagers, celebrities, and disabled persons (see table 2). The government outlined the problem in "The Ministerial Meeting for Extermination Four Kinds of Major Violence" (Korea Ministry of Information and Communication, 2005, pp. 1-5). In addition, victims of Internet cyberbullying organized the Association of Victims of Internet Portal Sites in July 2005. They argued that the government should adopt policies that would protect them. The victim association held a press conference and announced that "defamation and groundless rumors are rampant in news replies, Internet boards, and blogs managed by the major portals." They also argued that the current regulations were not sufficient to protect victims from cyberbullying. They requested a conference with the minister of Korea Ministry of Information and Communication to discuss new policies for preventing cyberbullying. 6

As a result of the incidents and the response to them summarized in table 2 and the efforts of victims of cyberbullying, the policy target population gradually changed; in addition to politicians, the general public came to be regarded as potential victims as well. This changing policy target population was constructed as an advantaged one that deserved protection. All of these changes led to changes in policy.

The kinds of incidents summarized in table 2 also compounded the negative image of netizens. According to this negative viewpoint, netizens were supposed have to made the Internet a new political space for open discussion and direct participation in the political process, but instead they wasted the opportunity. This response moved the

6. See "Internet portal, take responsibility for cyber violence," Chosun.com, July 7, 2005, http://news.chosun.com/svc/content_view/content_view.html?contid=2005070770256. 
Table 2. Cases of Damage Caused by Misuse of Internet Boards

\begin{tabular}{|c|c|c|}
\hline Cases & Date & Description \\
\hline $\begin{array}{l}\text { X-files of } \\
\text { celebrities }\end{array}$ & January 2005 & $\begin{array}{l}\text { Information pertaining to } 99 \text { famous celebrities is allegedly } \\
\text { leaked. }\end{array}$ \\
\hline $\begin{array}{l}\text { abuse against } \\
\text { newborn infant }\end{array}$ & April 2005 & $\begin{array}{l}\text { Some nurses upload pictures showing the infant abuse, } \\
\text { spreading suspicion about all the maternity wards in the } \\
\text { country. A full-scale investigation follows. }\end{array}$ \\
\hline $\begin{array}{l}\text { runaway girl } \\
\text { case }\end{array}$ & April 2005 & $\begin{array}{l}\text { A female teacher commits suicide after being falsely accused } \\
\text { of administering corporal punishment. The middle-school girl } \\
\text { who accused the female teacher is harangued by critics on } \\
\text { an Internet board and runs away from home. }\end{array}$ \\
\hline Twist Kim case & April 2005 & $\begin{array}{l}\text { A celebrity named Twist Kim is falsely accused of running an } \\
\text { Internet pornography site on account of the owner of the site } \\
\text { using his name. }\end{array}$ \\
\hline $\begin{array}{l}\text { Assault to } \\
\text { handicapped } \\
\text { child }\end{array}$ & May 2005 & $\begin{array}{l}\text { An incident wherein a handicapped child was beaten up is } \\
\text { posted on an Internet board, and personal information about } \\
\text { the assailant is subsequently illegally leaked. }\end{array}$ \\
\hline $\begin{array}{l}\text { Suicide of } \\
\text { Ms. X }\end{array}$ & May 2005 & $\begin{array}{l}\text { A story is posted about a woman who committed suicide } \\
\text { after she her boyfriend broke up with her. Netizens trace the } \\
\text { boyfriend and spread his personal information illegally. }\end{array}$ \\
\hline $\begin{array}{l}\text { False charge to } \\
\text { high school girl }\end{array}$ & May 2005 & $\begin{array}{l}\text { A high school girl commits suicide after being bullied. } \\
\text { The personal information of the assailants is leaked illegally, } \\
\text { and netizens demand on the Internet that the assailants be } \\
\text { punished. }\end{array}$ \\
\hline dog dirt girl & June 2005 & $\begin{array}{l}\text { Pet dog defecates in the subway. The owner doesn't clean it } \\
\text { up. The pictures containing this event are spread across the } \\
\text { Internet. Netizens trace the dog owner and leak information } \\
\text { about her on the Internet. }\end{array}$ \\
\hline
\end{tabular}

Source: adapted from Chin \& Ryou 2005, p. 2.

government to hire a research team to analyze the problem. The team suggested the introduction of a new policy that would further burden netizens by restricting anonymity on the Internet. During that period, the press sided with the government. There were 34 editorials that criticized the netizens among the total 39 editorials that addressed the topic. Furthermore, a public survey conducted by multiple research teams ascertained that even netizens agreed with the idea of introducing a policy that limited the right of netizens, in a roundabout way, as can be seen in table 3 . As a result, the social construction of the netizen gradually changed to deviant.

Internet companies, major portals in particular, were likewise saddled with a negative image on the grounds that they were not properly monitoring and managing their sites (Korea Ministry of Information and Communication, 2005, pp. 1-5). Additionally, 
Table 3. Survey Results Regarding Public Opinion on the Introduction of the Limited Verification of Identity Policy

\begin{tabular}{l|c|c|c|c}
\hline \multicolumn{1}{c|}{ Managing Institution } & Period (2005) & Participants & Support (\%) & Opposition (\%) \\
\hline Naver (portal site) & $9.12-10.13$ & 4,947 & 76.2 & 23.7 \\
\hline YMCA & $9.9-9.14$ & 2,079 & 71.7 & 8.2 \\
\hline ETNEWS (Internet newspaper) & $9.23-9.30$ & 203 & 75.0 & 25.0 \\
\hline
\end{tabular}

Source: adapted from Chin \& Ryou 2005, p. 5.

Table 4. Incident Rate of Damage by Types of Internet Sites (\%)

\begin{tabular}{l|c|c|c}
\hline \multicolumn{1}{c|}{ Type of Damage } & Internet Portal & Press Website & Internet Newspaper \\
\hline Defamation & 69.0 & 12.0 & 19.0 \\
\hline leakage of personal information & 61.6 & 11.2 & 27.2 \\
\hline spreading of false information & 61.2 & 14.1 & 24.7 \\
\hline
\end{tabular}

Source: adapted from Korea Ministry of Information and Communication 2006.

victims severely criticized portal sites that published sensational or tabloid content. This led a demand that they manage and block questionable content uploaded by their users. In addition, the idea of a policy that regulated Internet companies on the basis of the number of daily visitors gained support, since there was research showing that sites with higher user counts are used more frequently for cyberbullying than sites with fewer daily visitors (see table 4). Major portal sites and the big Internet newspapers thus came to be seen as contenders requiring regulation to prevent their evading responsibility in the management of their sites. The new regulations obligated Internet sites to install programs for verifying identity, but since, as already noted, most Internet companies already had these programs in membership method and since, in addition, the responsibility of managing questionable content might be understood as the right to delete any reply using the arbitrary standards of a given Internet site, the policy burden placed on Internet companies by the new regulations was largely symbolic.

\section{Consolidation in the Meaning of the Policy Target Population}

Even with the implementation of the limited verification of identity policy, it was necessity to implement specific policies designed to protect victims of Internet cyberbullying. Groundless rumors about celebrities, illegal release of personal information, and defamation were problems. In particular, the suicide of Choi Jinsil (a famous South Korean actress) over groundless rumors about here produced social shock. This 
and other incidents of cyberbullying led to a consolidation in the social construction of the victim as the advantaged. Additionally, groundless rumors regarding government policy about the negotiations over beef imports with the U.S government found their way onto Internet boards in this period. This was an important development that alerted the government to the fact that misuse of the Internet had spread to formal policy matters. So, the government sought to revise the regulation to protect the policy sector and government activity.

The ruling party and Korean Communications Commission tried to extend the jurisdiction of the government and to use the cyber defamation article in the Promotion of Information and Communication Network Utilization and Information Protection Act to legitimize government investigation even if a victim had not filed a suit. Whether this proposal would pass or not hinged on the social construction of netizen, victims, and Internet companies. Although the government represented netizens in negative way, and the press followed suit with 82 editorials among the 105 total editorials that proffered a view of netizens adopting a negative tone, politicians in the opposition party voiced objections to revising the law. In the wake of changes to the political structure of National Assembly and the 2008 presidential election, the opposition party, NGOs, and netizens using Daum Agora, one of largest South Korean Internet bulletin boards, allied in the name of opposing the domination of broadcast media and the suppression of netizens. ${ }^{7}$ They proclaimed that they desperately opposed the proposal of the government and the ruling party. This opposition did not seriously challenge the social construction of the netizen as deviant, but it did make it more likely that instead of the government securing the right to investigate, the limited verification of identity would merely be extended.

The social construction of Internet companies as contenders was likewise consolidated. The negative image of Internet companies had gradually intensified due to a growing number of incidents of cyberbullying. Internet companies had been criticized for taking advantage of such incidents to gain more users and for not taking responsibility for managing their sites. Thus, regardless type of service or contents they offered, they became subject to regulation based on the number of daily visitors, which amounted to extending the range of the limited verification of identity policy.

7. See "Democratic Party holds a rally with candles in the rain to protest media domination," Hankyoreh, July 25, 2008, http://www.hani.co.kr/arti/society/society_general/300843.html. 


\section{Reconstruction of the Policy Target Population}

Due to continuous defamation and groundless rumors spread of the Internet, the social construction of the policy target population who needed policy protection was maintained as the advantaged. In addition, the target population requiring protection had vastly expanded owing to social events such as leaked personal information (see table 5). Indeed, the number of victims of leaked information exceeded the number of victims of cyberbullying. Therefore, the prevention of leaked information came to assume priority in Korea.

Table 5. Cases of Massive Personal Information Leaks

\begin{tabular}{l|c|l|c}
\hline \multicolumn{1}{c|}{ Cases } & Dates & \multicolumn{1}{c}{ Description } & $\begin{array}{c}\text { Leak Scale } \\
\text { (Million) }\end{array}$ \\
\hline $\begin{array}{l}\text { game } \\
\text { company }\end{array}$ & 2011.11 & $\begin{array}{l}\text { Back-up server of online game site is hacked and } \\
\text { personal information (ID, name, encoded password, } \\
\text { and social security number) is leaked. }\end{array}$ & 13.2 \\
\hline portal site & 2011.7 & $\begin{array}{l}\text { User information file (name, ID, telephone number, } \\
\text { e-mail address, social security number and } \\
\text { password) is leaked by hackers. }\end{array}$ & 35 \\
\hline Bank & 2011.6 & $\begin{array}{l}\text { Illegal dealers of personal information buy leaked } \\
\text { personal information from hackers and use the } \\
\text { information to sending mobile texts illegally. }\end{array}$ & 19 \\
\hline $\begin{array}{l}\text { Capital } \\
\text { company }\end{array}$ & 2011.4 & $\begin{array}{l}\text { Personal client information (social security number, } \\
\text { password for loan) is leaked. }\end{array}$ & 1.75 \\
\hline
\end{tabular}

Source: Adapted from Korea Government Personal Information Protection Commission 2012, pp. 54-55.

The social construction of the netizen thus underwent a transformation. Netizens themselves were the most harmed group by these leaks. The leak of personal information caused multiple problems; there were numerous victims, it was difficult to ascertain the level of damage, it was easy for the leaked information to be used in the commission of another crime, and it was hard to get legal help (Kim, 2013, pp. 72-73). The leak of personal information impacted all Internet users.

Contributing to the change in the meaning of netizens at this time was the Peoples' Solidarity for Participatory Democracy's submission of a constitutional petition to the constitutional court of Korea. ${ }^{8}$ In the petition, the group claimed that the limited

8. See www.peoplepower21.org/PublicLaw/600651for the petition. See also "The constitutional petition against the limited verification of identity by the Peoples' Solidarity for Participatory Democracy," Kyunghyang Shinmun, January 26, 2010, p. 12. 
verification of identity law infringed on the freedom of expression and right to privacy protection, which are constitutionally guaranteed rights. Moreover, the group argued that anonymous expression on the Internet is in the public interest because it permits the dissemination of new thoughts. The petition made the case for seeing netizens as a policy target population that needed to be protected so that they were able to exercise their rights and serve the public interest rather than as a policy population whose rights ought to be constrained. Both the increase in the leak of personal information and the petition helped rapidly transform the image of netizens from negative to positive, and they were no longer viewed as deviants but rather as the advantaged. The Korea Communications Commission announced a plan to prevent further leaks and to protect personal information in a campaign in 2012. The commission also announced a plan that prevented the saving and distribution of social security numbers on the network after 2014 (Korea Communications Commission, 2011b; 2011c). Subsequently, the limited verification of identity policy ceased to match the social construction of netizens, which led to a revision of the policy regulating Internet use.

Changing market conditions had an impact on the meaning of Internet companies. As shown in table 6, they still held a monopoly with respect to portals. However, international companies gained a competitive advantage over domestic companies in new emerging market such as social networking sites. Furthermore, international companies such as Google did not have to enforce the limited verification of identity law. ${ }^{9}$ With these market conditions, a new opinion emerged that domestic Internet companies needed political support, not regulation. ${ }^{10}$ The government recognized that a new policy was needed to both break up the oligopoly in the domestic market and to support domestic Internet companies under international market conditions. Moreover, the Internet media asserted their right to provide a forum for the free expression of public opinion. Media Today, for instance, submitted a constitutional petition to the constitutional court of Korea in which it argued that rights of Internet media to provide such forums was severely restricted. ${ }^{11}$ Bloter.net evaded the limited verification of identity requirement by changing to a social networking site and presenting its case

9. See "Has Google changed?," Dong-a-ilbo, August 25, 2010, and "Korea Communications Commission announces that 'SNS reply services are not object of the limited verification of identity'; the limited verification of identity is proved to be a mere scrap of paper," Hankyoreh, March 8, 2011, p. 1.

10. "A succession of failures for overseas expansion of Korean portal sites," Kyunghyang shinmun, August 17, 2010, p. 18.

11. See "Submitting the constitutional petition against the limited verification of identity," Hankyoreh, April 15, 2010, p. 13. 
Table 6. Market Share of Search Engines and Social Networking Sites of Korea in 2012 and 2013

\begin{tabular}{|c|c|c|c|c|c|}
\hline \multirow{2}{*}{$\begin{array}{l}\text { Social } \\
\text { Networking } \\
\text { Site }\end{array}$} & \multicolumn{2}{|c|}{ Average Market Share } & \multirow{2}{*}{$\begin{array}{l}\text { Search } \\
\text { Engine }\end{array}$} & \multicolumn{2}{|c|}{ Average Market Share } \\
\hline & $\begin{array}{c}2012 \\
(\%)\end{array}$ & $\begin{array}{c}2013 \\
(\%)\end{array}$ & & $\begin{array}{c}2012 \\
(\%)\end{array}$ & $\begin{array}{c}2013 \\
(\%)\end{array}$ \\
\hline Facebook & 70.59 & 77.62. & Naver & 74.47 & 78.56 \\
\hline Youtube & 26.94 & 21.15 & Daum & 16.01 & 15.00 \\
\hline ME Today & 1.29 & 0.99 & Google & 5.91 & 3.56 \\
\hline Cyworld & 0.68 & 0.19 & Nate & 1.41 & 1.16 \\
\hline Twitter & 0.46 & 0.01 & Yahoo Korea & 0.72 & 0.22 \\
\hline
\end{tabular}

Source: Internet Trend, www.internettrend.co.kr.

regarding the right to provide a forum for public opinion. ${ }^{12}$ These interventions supported the idea that Internet media and companies in South Korea should have the right and freedom to manage their sites as they saw fit, and it is arguable that the result of these efforts is that Internet service providers are now no longer seen as contenders but instead the advantaged.

\section{CONCLUSION}

While there are various theories that explain policy change, this study emphasizes social constructivism and explains it by exploring contribution of the meaning of target populations. The study draws on the model of the social construction of target populations that Ingram and Schneider (1993) have developed. As the groups requiring protection expanded and netizens came to be represented as deviants, the government's direct regulation become strict and imposed a burden on netizens. However, after Internet service providers and netizens, the targets of regulation, were transformed into a protected group, they came to be seen as the advantaged group, and the government's regulation gave way to self-regulation by the Internet service providers.

In addition, our study shows that the interaction between actors and structural and

12. See "Submitting the constitutional petition against the limited verification of identity," Hankyoreh, April 15, 2010, p. 13, and "Korea Communications Commission announces that 'SNS reply services are not object of the limited verification of identity'; the limited verification of identity is proved to be a mere scrap of paper," Hankyoreh, March 8, 2011, p. 1 . 
institutional variables such as presidential elections and National Assembly members or market conditions has an effect on the way target populations are viewed. In the case of Internet regulation in Korea, the rights of politicians ended up being trumped by the importance of personal and public gains. In this process, the government and the ruling party exercised their legislative power, and the victims of cyberbullying and NGOs organized. The interaction among these actors was characterized by conflict rather than by active and voluntary agreement or self-directed learning, and conflicts were particularly strong when the interactions were about policies regarding the government or politicians such as those protecting political parties or their candidates, about the spreading of rumors about a policy, or between politicians and progressive NGOs. We speculate that one cause of these conflicts is the lack of an institutionalized setting for debate in South Korea.

We have also examined the conditions for path-dependent or radical changes in target populations and have offered a theoretical expansion of the social construction of target populations. According to our analysis, when influence factors exercise a positive effect on a group's image and power, the group becomes the advantaged one and, if that effect is exercised extensively, then the change is radical. Groups that secure protection consolidate their position as the advantaged group through their interaction with events that have a restrictive but positive effect on image and power. While netizens were initially categorized as deviants as a result of their interaction with social and political events that had restrictive but negative effects on their image and power, service providers of the Internet were initially categorized as contenders because of events that exerted restrictive and negative effects on their image. However, in general, economic events that had positive effects on their image and power rapidly changed netizens into the advantaged group, and service providers with power became an advantaged group due to their positive image.

Finally, we have demonstrated that the political identity of target populations differs from their social one. Their time-periodic identity is formed by interaction between these two identities, and policy change is a function of this time-periodic identity. This study concludes that these two identities are distinct and shows that target populations come to be defined as the distinction between the two identities blurs.

\section{REFERENCES}

Ang, P. H. 2009. Growing up: The maturing of the Internet and the implications for internet governance. Korean Journal of Policy Studies, 24(2): 117-132.

Archer, M. 1995. Realist social theory: The morphogenetic approach. Cambridge: 
Cambridge University Press.

Bensonsmith, D. 2005. Jezebels, matriarchs, and welfare queens: The Moynihan report of 1965 and the social construction of African-American women in welfare policy. In A. Schneider \& H. Ingram (eds.), Deserving and entitled: Social constructions and public policy (pp. 243-260). Albany: State University of New York Press.

Berger, P. L., \& Luckmann, T. 1966. The social construction of reality: A treatise in the sociology of knowledge. Garden City, NY: Doubleday.

Burr, V. 2003. Social constructionism. New York: Routledge.

Carney, G. M. 2010. Citizenship and structured dependency: The implications of policy design for senior political power. Ageing and Society, 30(20): 229-251.

Chin, Y., \& Ryou, S. H. 2005. Limited real-name policy: Is that an appropriate policy for eradicating cyberviolence? Seoul: Office of National Assembly Member Y. Chin.

Cho, S. J. 2009. The Internet and Korean democracy. Paju-si, Gyeonggi-do: Korean Studies Information.

Cho, S. Y. 2007. A constitutional study of Internet-related rulings in public office election law. World Constitution Law Review, 13(1): 41-64.

Choung, W. 2009. The recent wave of cybercrime and legal measurements. Law Reasearch Institute of Hongik University, 10(1): 195-244.

Christou, G., \& Simpson, S. 2006. The internet and public-private governance in the European Union. Journal of Public Policy, 26(1): 43-61.

Conrad, P., \& Barker, K. K. 2012. The social construction of illness: Key insights and policy implications. Journal of Health and Social Behavior, 51(S): S61-S79.

Cronley, C. 2010. Unraveling the social construction of homelessness. Journal of Human Behavior in the Social Environment, 20(2): 319-333.

DeLeon, P. 2005. Social construction for public policy. Public Administration Review, 65(5): 635-637.

DiAlto, S. J. 2005. From "problem minority" to "model minority": The changing social construction of Japanese Americans. In A. Schneider \& H. Ingram (eds.), Deserving and entitled: Social constructions and public policy (pp. 81-110). Albany: State University of New York Press.

Donovan, M. C. 1993. Social constructions of people with AIDS: Target populations and United States policy, 1981-1990. Review of Policy Research, 12(3-4): 3-29.

Edvardsson, B., Tronvoll, B., \& Gruber, T. 2011. Expanding understanding of service exchange and value co-creation: A social construction approach. Journal of the Academy of Marketing Science, 39(2): 327-339.

Gergen, K. J. 2009. Social construction. Thousand Oaks, CA: SAGE. 
Ha, T. S. 2009. An analysis of the revision of the Government Organization Law at the outset of the Kim Dae-jung administration. Korean Public Administration Quarterly, 21(2): 457-489

Hall, P. A. 1993. Policy paradigms, social learning and the state: The case of economic policy making in Britain. Comparative Politics, 25(3): 275-296.

Hogwood, B., \& Peters, B. G. 1983. Policy dynamics. New York: St. Martin's Press.

Huh, K. M., \& Baek, C. H. 2006. A study of the consolidation of law pertaining to the Internet BBS real-name system. Korean Criminological Review, 66: 173-204.

Hwang, Y. S. 2007. A critical approach to the implementation of a real-name system on Internet bulletin boards: Exploring the right of anonymous communication. Media and Society, 15(2): 97-130.

Ingram, H., \& Schneider, A. 1995. A response to Robert Lieberman. American Political Science Review, 89(2): 441-446.

Ingram, H., Schneider, A. L., \& DeLeon, P. 2007. Social construction and policy design. In P. A. Sabatier (ed.), Theories of the policy process (pp. 93-126). Boulder, CO: Westview.

Jang S. H. 2011. Conflicts surrounding the Internet real-name system: Its process and characteristics. Journal of North-East Asian Studies, 59: 99-118.

Jensen, L. S. 2005. Constructing and entitling America's original veterans. In A. Schneider \& H. Ingram (eds.), Deserving and entitled: Social constructions and public policy (pp. 35-62). Albany: State University of New York Press.

Jho, W. S., \& Kim, J. M. 2010. Evaluation of the decision-making governance of Internet regulation policies. Korea Association for Policy Studies, 19(3): 57-79.

Jurik, N., \& Cogwill, J. 2005. The construction of client identities in a post-welfare social service program: The double bind of microenterprise development. In A. Schneider, \& H. Ingram (eds.), Deserving and entitled: Social constructions and public policy (pp. 173-196). Albany: State University of New York Press.

Kang, K. K. 2003. The election of public officials in the age of Internet media. Constitutional Law Research, 9(3): 119-148.

Kim, H. K. 2005. The law pertaining to the election of public pfficials and the Internet real-name system. Korean Criminological Review, 64: 203-232.

Kim, J. H. 2013. Private law remedies for personal information infringement. MA thesis., Soongsil University.

Kim, M. H. 2005. A policy study from the viewpoint of social constructivism: The theory of the social construction of target populations and its application. Korea Association for Policy Studies, 14(3): 31-57.

Kim, M. H., \& Ahn, H. K. 2006. The transformation of the social perception of target populations and policy change. Korean Public Administration Review, 40(4): 
469-490.

Kim, S. H. 2009a. An exploration of the critical realist approach to institutional change: A comparison with historical institutionalism. Korean Journal of Policy Studies, 47(2): 337-374.

Kim, S. H. 2009b. Lag in health care reform in Korea and actor-centered institutionalism: The case of the DRG payment system policy. Korean Policy Sudies Review, 18(1): 125-155.

Korea Communications Commission. 2009. Subject selection of limited verification of identity in 2009, January 30.

Korea Communications Commission. 2010. Subject selection of limited verification of identity in 2010, February 2.

Korea Communications Commission. 2011a. Subject selection of limited verification of identity in 2011, September 3.

Korea Communications Commission. 2011b. Completion of personal information protection campaign with 134 representatives of internet business in 2011, October 20.

Korea Communications Commission. 2011c. Establishment of basic communication and broadcasting plan, Novemer 11.

Korea Communications Commission. 2012. Restrictions on collection and use of social security numbers, April 5.

Korea Government Personal Information Protection Commission. 2012. 2012 Personal information protection annual report. Seoul: South Korea Korea Government Personal Information Protection Commission.

Korea Ministry of Information and Communication and Korea Network Information Center. 2004. 2003 survey on computer and Internet use. Seoul, Korea: Wooseong Press.

Korea Ministry of Information and Communication. 2005. Public hearing for amendment to act promoting information and communication network utilization and information protection.

Korea Ministry of Information and Communication. 2006. 2005 Audit and inspection of ministry of information and communication conducted by the national assembly.

Korea Press Foundation. 2001. Internet press of Korea: Real condition and problem. Seoul: Korea Press Foundation.

Lasswell, H. D. 1951. The policy orientation. In D. Lerner \& H. D. Lasswell (eds.), The policy science (pp. 3-15). Stanford, CA: Stanford University Press.

Lee, B., Karen, M. L., \& Lee, K. J. 2005. Agenda-setting and the Internet: The intermedia influence of Internet bulletin boards on newspaper coverage of the 2000 
general election in South Korea. Asia Journal of Communication, 15(1): 57-71.

Lee, H. W. 2008. The discursive construction of cyberviolence in real-name online interaction: A critical discourse analysis. Economy and Society, 79: 112-115.

Lowry, W. 2006. Potential focusing projects and policy change. Policy Studies Journal, 34(3): 313-335.

Majone, G. 1989. Evidence, argument, and persuasion in the policy process. New Haven, CT: Yale University Press.

Mucciaroni, G. 1995. Reversals of fortune: Public policy and private interests. Washington, DC: Brookings Institution Press.

National Assembly. 2004a. 1st proceeding of Subcommittee of the Election Act. Special Committee of Political Reform. 244th provisional session of the National Assembly.

National Assembly. 2004b. 11th Proceeding of Subcommittee of the Election Act. Special Committee on Political Reform. 244th provisional session of the National Assembly.

Newton, L. 2005. It is not a question of being anti-immigration: Categories of deservedness in immigration poolicy making. In A. Schneider \& H. Ingram (eds.), Deserving and entitled: Social constructions and public policy (pp. 139-167). Albany: State University of New York Press.

Park, I. S. 2010. Freedom and the limits of election campaigns on the Internet. Journal of Electoral Studies, 1(1): 33-54.

Park, S. I. 2003. Political reform: What and how we reform. National Assembly Review, 446: 72-77.

Powell, J. L., \& Hendricks, J. 2009. The sociological construction of ageing: Lessons for theorising. International Journal of Sociology and Social Policy, 29(10-2): 84-94.

Scharpf, F. 1997. Games real actors play: Actor-centered institutionalism in policy research. Boulder, CO: Westview.

Scharpf, F. 2000. Institutions in comparative policy research. Comparative Political Studies, 33(6-7): 762-790.

Schneider, A., \& Ingram, H. 1993. Social construction of target populations: Implications for politics and policy. American Political Science Review, 87(2): 334-347.

Schneider, A., \& Ingram, H., eds. 2005. Introduction: Public policy and the social construction of deservednss. In A. Schneider \& H. Ingram (eds.), Deserving and entitled: Social constructions and public policy (pp. 1-33). New York: State University of New York Press.

Schneider, A., \& Sidney, M. 2009. What is next for policy design and social construction theories? Policy Studies Journal, 37(1): 103-119. 
Schram, F. S. 2005. Putting a black face on welfare: The good and the bad. In A. Schneider \& H. Ingram (eds.), Deserving and entitled: Social constructions and public policy (pp. 261-290). Albany: State University of New York Press.

Schroedel, J. R., \& Jordan, D. R. 1998. Senate voting and social construction of target populations: A study of AIDS policy making, 1987-1992. Journal of Health Politics, Policy and Law, 23(1): 107-132.

Seo, J. K. 2008. A study of the social construction of policy dilemmas with a focus on frame analysis. Korea Association for Policy Studies, 17(2): 119-149.

Sung, W. J. 2014. A study of the policy process behind limited verification of identity on the Internet. Korean Public Administration Review, 48(1): 233-262. 